\title{
Education for Water
}

\author{
DENISE DE LA CORTE BACCI \\ e ERMELINDA MOUTINHO PATACA
}

\section{Foreword}

W

ATER has a major importance for the maintenance of life in the planet and, therefore, to talk about the significance of its knowledge, in their several dimensions, is to talk about the survival of the human species, the conservation of the biodiversity balance and the dependence relations among living creatures and natural environments.

The presence or absence of water writes history, creates cultures and habits, determines the occupation of territories, wins battles, ends and provides life to the species, determines the future of generations. Our planet wouldn't have become a proper environment for life without water. Since its origin, the elements hydrogen and oxygen combined to originate the key element of life's existence.

Under a privileged condition, it enabled the species to evolve and man to exist and to live in this planet. Throughout thousands of years, our species occupied territories, grew and developed based on such an important and valuable natural good which is water. However, throughout history, there were changes in the relationship between man and nature and, as a result, in his relationship with water.

In the society where we live, water started to be seen as a hydric resource and no longer as a natural good, available for human existence and that of the other species. We started to use it in an indiscriminate manner, always finding new uses, without assessing the environmental consequences in relation to the quantity and quality of water.

Besides the population growth in global scale in the last century, the intensity of the shortage increased in certain regions of the planet, mainly due to human factors related to the occupation of land, pollution and the contamination of both the superficial and the underground bodies of water.

In our society, the exploration of the natural resources, among which is water, in a very aggressive and uncontrolled way, led to a very deep social and environmental crisis. Today we're facing a situation in which we're threatened by that crisis, which may become one of the most serious problems to be faced in this century.

That crisis is based on multiple aspects - social, economic, cultural, technological and environmental ones - depicted in the increase of poverty, the 
absence of basic sanitation, the pollution of the rivers and aquifers, the act of putting down the woods, the agricultural and cattle raising expansion, the urbanization and industrialization, the occupation of the spring areas, the poor management of the available hydric resources. That crisis started due to the worldview centered on the utilitarianism of the natural goods, which has been described by several authors, among whom are Soffiati (1992), Grün (1996), Carvalho (2004), Loureiro (2004), Guimarães $(2004,2006)$ and on the kind of development that the society chose, as well as its current relationships with the environment.

According to Tundisi (2006), the economic development and the complexity of the human societies' organization, produced several changes in the hydrological cycle and in the water quality, which is even affected by the activities of a religious nature.

The solution of complex problems, such as misery, the proliferation of environmental disasters, the lack of natural resources, among others, is a challenge which has been mobilizing scientists, politicians and community members from all the regions of the planet.

Water is a broad theme and may be addressed from different points of view. In this article, we chose to approach education for water based on two dimensions: space and time (the latter dealing both with the geological time and human history). The decision to approach the education for water from those dimensions is due to the fact that without them it's impossible to face the knowledge fragmentation which prevails in the school environment, preventing the integrated analysis of real problems, turning difficult the relationship of concepts, procedures and attitudes in the different disciplines.

Under that perspective, it's necessary to understand the relationship between man and nature throughout time.

\section{Social and disciplinary fragmentations}

The crisis we referred to is the result of a long process of appropriation and destruction of nature, which was deeply intensified with the development of industrial capitalism, based on the appropriation of nature. The technological production, which is the support of capitalism, is grounded in the scientific development, which configures the modern society characterized by an extreme social and cultural fragmentation in which knowledge is increasingly compartmentalized.

What might have led to the fragmentation of knowledge and of the society? How could we seek solutions of articulation among the kinds of knowledge? Is it possible to integrate knowledge in school practices? We believe that such questions can be answered when they are treated within a context, relating time and space in the production of knowledge, in such a way that we understand the fragmentation process of the kinds of knowledge and the creation of new practices and attitudes. Thus, the history of the sciences together with the environmental education can serve as a teaching methodology that reveals a complexity of factors which conditioned the current situation and that may indicate ways for the reflection and the elaboration of new possibilities to invert the current context. 
The transition between feudalism and modern society, marked by the development of mercantilism, took place slowly and in a very heterogeneous way in the European countries since the $15^{\text {th }}$ Century. The commercial society which was emerging brought practical needs to its development and increasingly required the building of machines and artifacts together with the development of math and, as a result, the quantification of nature. Man turned himself increasingly to the observation of nature, with a practical and utilitarian purpose which enabled the accumulation of capital. The building of knowledge was based, at the time, on a strong relationship between science and technique, so as to solve the demand for technological instruments that came from the society being transformed (Rossi, 1989).

That social transformation process also formulated a new scientific method. During the Middle Ages, nature was mainly interpreted according to principles of Scholastics, that is, the building of theories about nature was based exclusively on the reading and interpretation of the Bible. During the Renaissance, the new context imposed by mercantilism imposes a new relationship between man and nature. The need for raw material to operate the commercial relations leads to a direct observation of nature and of experimentalism.

The principle of utilitarianism was the main explanation for studying nature, as advocated by Francis Bacon, since it would reveal forms of appropriation and use of the beings of all three Kingdoms of Nature (minerals, vegetables and animals), the territorial occupation, the human domination and the intensive use of the hydric resources. Thus, science should provide the material development of society, relating the study of nature with the means of production.

The valuation of the practical activities and of the building of machines, necessary to the development of the urban nuclei, the large scale production of merchandises, the development of sailing by means of the building of more precise instruments to measure both latitude and longitude, conditioned a new way to observe the universe. In that context, the use of water determined the territorial expansion and became related to a new world conception. The development of sailing, necessary for a commercial and territorial expansion intended by the European countries, required the knowledge of the climate, hydrography, astronomy and math. Thus, the modern man turned himself to the direct observation of nature and to the knowledge of its operation which enabled its material use.

The metaphor of a machine-universe was used by the philosophers, mainly René Descartes, as a new form of interpretation of nature, in which the operation of the universe depended on each of its parts. For the understanding of the machine's operation, the universe could be divided into several isolated parts (or pieces), which would later be rearticulated for the understanding of the whole.

However, some philosophers, mainly French in the $18^{\text {th }}$ Century, such as D'Alembert, advocated an organicist way to observe nature, that is, the universe was imagined as an organism, the operation of which took place in an integrated whole. In the same way as the human body or the living organisms, the operation took place in a balanced relationship between the parts (Abrantes, 1998). 
The mechanicist conception had a great influence on the development of the natural sciences, configuring itself mainly in the Enlightenment, during the $18^{\text {th }}$ Century. Such presupposition results in the division of nature in ever smaller parts, which multiplies the fragmentation of science. Francis Bacon already idealized a division of knowledge, structured in three great groups: memory (history), reason (philosophy or science) and imagination (poetry, or arts as currently conceived). What is currently understood as science was related to reason and memory, where they were both divided into three parts: the science of God, the science of man and the science of nature.

In turn, history was divided into sacred, civil and natural. There were already other subdivisions in knowledge, which leads us to observe the beginning of its fragmentation. However, until the $18^{\text {th }}$ Century, the philosophers didn't dissociate the natural issues from the human ones, and the same thinker approached all the issues and investigated objects related to nature or to the human relations. Therefore, until that moment the specialization of knowledge hadn't taken place yet.

It was after the Industrial Revolution that the movement of specialization or fragmentation of knowledge became more intensive. The social division of labor in our contemporary society led to a fragmentation which was ever more intensive of knowledge in several isolated disciplines, often related to the several sectors of industrial production. Society itself fragmented into distinct social groups, becoming increasingly unequal and heterogeneous.

The anthropocentric ethics deeply influenced modern education, which was felt in the reformulation of the curricula, which were basically inspired by Bacon's ideas in which nature clearly had a utilitarian value. Besides, in the $19^{\text {th }}$ Century, the commercialized and industrialized world required the presence of the sciences in the curriculum, seen from the rationality point of view, which contributed to perpetuate the idea of objectified nature (Grün, 1996).

Pragmatism, individualism and rationalism, pillars of the North American curricular thought, base themselves on utilitarian ethics, which only consider nature in relation to its use value and that education consists only in the individuals and their learning, as if nature didn't exist (Grün, 1996).

In the beginning of the $21^{\text {st }}$ Century, we are undergoing an emergency which, more than ecological, is a crisis of the thought style, the social imaginaries, the epistemological presuppositions and the knowledge which supported modernity. A crisis of the being in the world, which is fully manifested: in the internal spaces of the subjects, the self-destructive social behavior, the external spaces, the degradation of nature and the life quality of the people (Jacobi, 2005).

\section{The integration of kinds of knowledge - interdisciplinary paths in the environmental education and in the geosciences}

The long historical process presented led to a great fragmentation of knowledge and to a very deep separation between man and nature. On behalf of the objectivity, precision and acceptance of the scientific theories, the scientific 
method advocated the "neutral nature" of the observer in the face of his experiments and the creation of his theories. Such premises are currently being conceived by some critics, as one of the causes of environmental degradation and the crisis of modern society.

Under such perspective, one of the issues approached in the debates on environmental education is the criticism to the extreme rationality of modern science, which devaluates other human manifestations, such as sensitivity and spirituality. The sciences reveal an inadequacy of their epistemological presuppositions to an environmental perspective, which was translated by Isabel Carvalho $(2004$, p. 111) as the "Crisis of a way to know and the search for new ways to understand". The crisis pointed out by the author refers to the context indicated before, and the "search for new ways to understand" refers to some epistemological presuppositions of the environmental education, among which we find the disciplinary integrations.

Interdisciplinarity as principle and attitude is a focus of debate for researchers and teachers of various teaching levels who, upon acknowledging the complexity of the post-industrial world and the globalization process, experienced by the people of the whole world, are aware that the partial knowledge can't solve problems that require specific knowledge, related to a common and central goal (Pontuschka et al., 2007).

For an effective education, it's necessary to develop an integrated vision of the world that surrounds us, a vision that makes us understand the various spheres (hydrosphere, biosphere, lithosphere and atmosphere) and their inter-relationships, as well as the interferences that man generates in the environment where he lives.

The contents of the geosciences provide a crucial basis for the understanding of such inter-relationships in space and time, providing a panorama of Earth as a living and dynamic system. A central issue is to understand how the geosciences contribute to the formation of both the teacher and the students, considering the specificities of the sciences and of the school disciplines.

We emphasize that the geosciences, specifically geology, provide a great contribution to an integrated vision of the environment, but it's not a part of the school curriculum as a discipline, and the contents related to it are dispersed among the other disciplines, mainly Science and Geography. In the sphere of the various sciences, despite all the debate on inter-disciplinarity, a compartmentalized and isolated work is still carried out, with few interlocution among the people in charge of the several fields of knowledge.

According to Compiani (2005), the absence of the integral development of the geosciences contributes to perpetuate the immediate and utilitarian vision of nature. Under that perspective, we can approach such themes as origin and evolution of the Earth, the formation of its materials and of its environments, conditions of likely origin of life, sedimentary record of the geological history of life and the geological processes in the evolution of life, conditions of concentration of the natural resources - mineral, hydric and energetic ones - and their possibility of renewal, sustainable conditions of use of the resources. 
Cuello Gijón (apud Gonçalves, 2006) emphasizes the potential nature of geology to serve as a nucleus directed towards interdisciplinary content approaches in the teaching of children and adolescents, and that the methodological and epistemological bases, related to the knowledge of the history of nature, are specially favorable to the systemic treatment of environmental themes, with significant possibilities for the educational work.

Guimarães (2004) points out to us that:

Through reason and specific procedures of Geology there's the characterization of the materials, the energy forms and their interactions in space and time, defining itself as a set of inter-related parameters which serve as a reference pattern of the physical means, built by the student. Such pattern leads to the understanding of the local physical environment and its relations with the social and cultural context, extending it to the broader context, until it reaches the conception of the Earth as a complex evolution system, which favored the emergence and evolution of the organisms, humankind and which changed the Earth's surface.

The dimensions space and time, which are often not approached in the teaching of science, present a crucial relevance for the understanding of the issues related to the environment in the education. They present themselves as educational strategies without which the integrated understanding of the environment is almost impossible.

According to Compiani (2007), the scales and their horizontal and vertical dimensions are approach methods that emphasize the processes for obtaining information, since, depending on the scale and the point of view of the person who interprets, a social and environmental problem will have different perspectives of theoretical and practical framing.

Ab'Saber (1991) states that the integrated perspective requires method, notion of scale, good perception of the relationships between time and space, understanding of the social and historical conjuncture of the environment that surrounds the students. It also requires respecting and believing in the value of the multiplicity and diversity of several worlds that co-exist in society, with the permanent exercise of the interdisciplinarity to deal with the daily issues.

The environmental history of a certain place can be better understood when it's inserted in the geological time, as of which the history and the origin of planet Earth are known, the dynamics of the system where we are inserted and of which we are part is understood, as well as the phenomena that took place throughout billions of years and the changes that took place during that period. Besides, it helps to promote the perception of the natural processes beyond the human life cycle and to understand the potential of the human actions on the natural environment, playing an important role in the existent relationships between the environment and society.

Thus, the theme water must be present in the educational context, both in the formal and in the non-formal education, with emphasis on the ethics and the formation of the citizen aware of his place in the world, in a real, dynamic world, 
which starts from the local and relates to the global, where all things may be part of a greater process, of an integrated system. Therefore, according to Compiani (2007), it's possible to leave the causality paradigm so rooted in the teaching of sciences and to practice a more contextualized teaching, to locate the phenomena in space and time, that is, to consider their historical aspect and, thus, to understand the complexity of the context and causality of a phenomenon.

Thus, education for water can't be centered only in our uses of it, but in the vision that water is a good that belongs to a larger and integrated system, which is a dynamic cycle subject to the human interferences. To understand the origin of the water, the hydrological cycle, the riverine dynamics and the phenomenon of the floods, the aquifers, as well as the geological risks related to the natural processes (silting up, floods) is crucial for us to understand the dynamics of the hydrosphere and its relationship with the other earthly spheres.

We believe that water is a theme of approximation of the deep and plural split knowledge and a theme that develops the interdisciplinary practice.

The development of a program that has water as its generating theme, in a proposition of interdisciplinary action, based on the fundamental concepts, in the explanation value and in the function of the geosciences, must be understood by the teachers in the deepest relationships between that content and the educational action, with collective, dialogic involvement and one with the exchange of knowledge.

The school, inserted within that social context, must be liable to the spread of knowledge, based on reality, in such a way as to move towards a new ethics and ways of living that are pertinent to society. According to Lorieri (2002), the school should provide a certain interconnection among the contents for the understanding of a certain reality which is not fragmented, but pregnant of relationships, and the interdisciplinary projects would help in the understanding of that complex and contradictory reality.

Therefore, the geosciences themes as central axis, which are currently spread among the various disciplines, with their physical, chemical and biological branches, can be dealt with in an interdisciplinary organization, overcoming the current fragmentation. It's possible to deal with the theme water since the early grades of Elementary School until High School, with different strategies and educational resources. Such approach is necessary to meet the intended goals of forming conscious citizens, who are able to assess and to evaluate the human activities that involve the use and the occupation of the environment, inside and outside the community where they are inserted.

The teaching and learning methodologies must benefit from the different strategies. In that case, the geosciences contribute to understand the extent, the diversity and the complexity of the environment and the multiplicity of variables within it.

The field lessons, as emphasized by Compiani \& Carneiro (1993), play a crucial pedagogical role, because it's in the field that there is the conflict between the real (the world), the exterior and the interior, the ideas and the representations, 
generating a unique context of observation and interpretation of nature in the search for information, in the understanding of the phenomena and in the formulation of explanatory concepts. According to the authors, the field is also the center of activities to teach the general method of conceiving the geological history of the Earth.

The study of the environment is an interdisciplinary teaching methodology which intends to unveil the complexity of an extremely dynamic determined space and one in constant change, the totality of which it's unlikely that an isolated school discipline can comprise (Pontuschka et al., 2007).

The study of the environment as a method that presupposes the dialogue, the formation of a collective work and the teacher as researcher of its practice, its space, its history, of the life of his people, of his students, has the goal to create the own curriculum of the school, setting ties with the life of his student and of his own, as citizen and as professional. The authors emphasize that a teaching project that uses that methodology carries out a movement of apprehension of the social, physical and biological space that takes place in multiple combined and complex actions. To learn the complexity of the real, it's necessary the existence of many looks, of the joint reflection and of actions towards the goal proposed by the work group (Pontuschka et al., 2007).

The use of that methodology to integrate the disciplines is ideal for the teaching and the learning by the students, in such a way as to contextualize the data of reality with the contents. The pedagogical interventions of each specific discipline contribute for the acknowledgement of the goals of the study. The theme water can be approached in many ways in the study of the environment, depending on the proposed goals.

The perspectives indicated above are being treated in the project "Elaboration of school and curricular knowledge related to science, society and the environment in the elementary school with emphasis in the regionalization based on the results of a Public Policies project," carried out in the Anhumas River Basin, in Campinas. The project is a partnership between professors and researchers from the Agronomy Institute of Campinas (IAC), the School of Education (FE) of the University of São Paulo (USP), the Institute of Geosciences (IG) and Institute of Biology (IB) of the University of Campinas (Unicamp) and of the state schools Adalberto Nascimento and Ana Rita Godinho Pousa. The project is coordinated by Prof. Dr. Maurício Compiani and relies on funding by Fapesp and Petrobrás.

The project is working on the perspective of the professor-researcher, that is, that the professor thinks about his own practice. Under that approach, we think how science is developed and how it articulates itself with the political, economic and social issues. Thus, interdisciplinarity had been taking place in the articulation among the professors involved in the project and the relationships will take place during the research practice of the professor. We consider that the educational researches are made up of three basic perspectives: the subjectivity of the professorresearcher, that is, its individual dimension; the constitution of the collective of 
professors and the articulation of the group; and, finally, the entire context in which the research is developed.

As for the context of elaboration, the project has been carried out locally in the Ribeirão Anhumas River Basin. That environmental dimension is extremely relevant in educational projects that deal with environmental perspectives.

\section{The importance of the river basin in education}

The complexity that involves the theme water in the school requires that the professor has an ability to explore the environment in a contextualized way.

The studies may start from the knowledge of the river basins as a guiding axis and rescue the local environmental history, with the goal to develop in the students an integrated vision of the different factors - both natural and human that condition the environmental changes.

The river basins are spaces characterized by their physical factors, but directly influenced by human occupation and by the action of the several social groups that install themselves there. Either in the rural or urban environment, the uses of water in the river basin are determined by the groups that occupy it and its interference on the physical environment takes place due to the interests of such groups. Therefore, the basins are, at the same time, a stage of natural processes and undergo changes carried out by man.

To work within the scope of the river basin promotes the understanding of the context, the unique and historical, and from which learning situations and strategies are created. The river basin can be taken as the place of the activities directed towards teaching the general method of conceiving the history of water in the planet. Knowledge about the origin of water, the hydrological cycle, the aquifers, the relation between precipitation and flow rate serve to insert it within a broad and complex interaction process in nature and relate it to society (multiple uses, occupation of spring areas, geological risks, pollution, contamination and management of the hydric resources).

The river basin can be the conductive axis of several disciplines, provide the development of scientific school practices, work as integration agent of the disciplines in the development of an encompassing vision of nature. Besides, it's in the river basin that the several social players meet for a negotiation of the multiple uses.

According to Tucci $(1993,1999)$, the river basin is a natural area for receiving the precipitation water which makes the flows converge to a single exit area, its discharge. A section of a river defines its river basin.

According to the conception of Tundisi et al. (1988, p. 314-5), the river basin is:

an important unit in the scientific investigation, training and integrated use of information for demonstration, experimentation, observation in real field work.

A basin can be used as a natural laboratory in which the ongoing and reinforced 
activity encourages the development of interfaces and progressively increase the understanding of processes and phenomena in a globalized way, instead of a compartmentalized one.

The river basin is adopted in the National Policy for Hydric Resources (Law n.9433/97) as territorial unit that encompasses water courses listed as "main" and/or "tributary", but it's not necessarily encompassing the aquifers. The law distinguishes between river and hydrological basin, which is the physiographic or geological unit that contains at least one aquifer of a significant size.

The river basins are the basic units for planning the use, conservation and recovery of the natural resources, according to the National Agrarian Policy Law (Law n. 8171/91).

The definition provided by the laws of an integrated unit in which the phenomena interact was crucial in the adoption of public policies for the management of the hydric resources, among which were that of the creation of the River Basin Consortia and Committees and the National Agency for Waters. That integrated vision, already established in the public policies, must be adopted when the school deals with the theme water.

Within the school context, the river basin must not be seen only as the main river and its tributaries, but, instead, as all volume from where the exchanges of matter and energy are verified, as well as the dynamics incited mainly by water, including both the surface forms and the ground water. The evaporation, the mineral changes that act upon the relief and the human action must be studied when dealing with river basin examined according to the aspect of delimitation of a volume in a space with a human history printed on it (Silva, 2003, in Pontuschka et. al., 2007).

Starting from the perspective of the environmental public policies, educational actions have been unfolding which have engaged the community in participation strategies for the environmental conservation and recovery.

In literature we find several projects developed in schools with different approaches of the theme water, but all of them articulating the curriculum to the context of the river basin: Tundisi et al. (1988, 1996), Leal \& Sudo (1998); Silva (2003, in Pontuschka et al., 2007); Romera e Silva (2004); Compiani (2006); Hagy \& Villanova (2007); De La Corte \& Figueiredo (2007); Lucatto \& Talamoni (2007).

It's important to emphasize that projects that present a contextualization of the problems involving water, present more effective results in relation to the issue of the awareness of teachers and students, who start to look at reality in a complex way. The authors mentioned above bring such experience with very positive results, emphasizing the improvement in the understanding of the content and changes of attitude of those involved in the teaching and learning process.

Braga et al. (2003) emphasizes that it's necessary to teach for the environment, and it's only based on local actions, the sensitization and the awareness of the 
individuals as citizens that participate in the process of developing a new society that we can change the destiny of the global problems that destroy the planet, and water is a primary issue.

According to Romera e Silva (2004), education and the preparation projects must turn easier the perception and the assessment of the local contradictions. The building of knowledge is a mediation factor in the management of conflicts among cultures, differentiated behaviors and interests of social groups, so that the transformations intended by society take place.

\section{Teaching in the waters of the Pirajuçara: \\ a proposal of environmental education}

With the concern to deal with the issue of water from the space and time dimensions, in an interdisciplinary way and having the river basin as the main focus, as discussed throughout this article, it was proposed the updating course "Teaching in the waters of the Pirajuçara: a proposal of Environmental Education", promoted by the group TEIA-USP (Education and Environment Laboratory) made up of students and professors of the School of Education (FE), Institute of Geosciences (IGc) and EACH (School of Arts, Sciences and Humanities of the University of São Paulo). We will make here a brief report of that ongoing course in a proposition of articulation between the theoretical perspectives discussed in this article with the practice of the training of professors.

The goals of the course are working the Pirajuçara river basin, from the physical, historical, social, economic and environmental aspects, the social participation, the evaluation of the meaning of environmental degradation in the hydric resources and the perception of the local reality. The course intends to provide subsidies for the formulation of projects and actions of environmental education in the schools. It also has the goal to encourage the exchange of information and experiences among the participants and the development of skills in the use of means of virtual communication for the formation of a multiplying network directed towards changes of attitude with a view to the sustainable use of water.

The proposition of the course is in accordance with the main goal of TEIA of building a space of research-action and knowledge production, reflection and debate on practices and environmental education policies in Brazil. Through the building of an interdisciplinary space, the group proposes the direct participation of the academic community in the debate and in the elaboration of public policies directed towards society as a whole, by bringing closer together the knowledge generated next to the public and private organs and the community in general by means of partnerships (www.teia.fe.usp.br).

The content of the course was structured in four modules, articulated among the members of the group, and defined as follows:

1) Environmental education, sustainability and participation. It's an approach about the relationships between education and environment with emphasis on the themes of sustainability and of social participation as axis that encourage 
the development of a critical thought. The module gives priority to readings that promote a theoretical deepening of the environmental education practices and permit the acquisition of a repertoire about the sustainability culture in its multiple dimensions, considering the social practices, the theme of citizenship and the cultural dimension in a context permeated by the growth of the environmental problems.

2) Water cycle in the planet - theoretical and methodological aspects. It addresses the origin of water in the planet, the hydrological cycle, with emphasis on the main phases and characteristics, underground water, aquifers; concepts of river basin, layout and basic parameters; interferences by man in the natural processes resulting in floods and slides; physical aspects of the Pirajuçara river basin. That module is articulated to a thematic workshop for the study of the river basin through the building of models.

3) Social, institutional and economic aspects of water. In that space there's the analysis the water policy, with emphasis on the National Policy of the Hydric Resources, the situation in the State of São Paulo and, specifically, in the Metropolitan Region of São Paulo. Emphasis is also given to the economic aspects of charging for water and other mechanisms and to the analysis about the impact of the social problems on the life quality and the management of the hydric resources.

4) Water: historical and geographic aspects. The methodological approach used here has to do with the historical relationship among science, technology, society and environment. A historical contextualization is made about the uses of water during the Brazilian colonial period, with emphasis on the natural conditioning factors for navigation that configured the formation of the Portuguese Empire between the $15^{\text {th }}$ and the $18^{\text {th }}$ Centuries. Besides, we emphasize the configuration of the Brazilian river basins associated to the conditioning factors of fluvial navigation as determining factors for the territorial expansion and of the political division of Portuguese America. Water was also a structuring element of the urbanization, in which there was a planning for building cities in strategic places in the Brazilian seashore and in the outfall of some rivers during the colonial period. Besides, some urban layouts also followed the configuration of the rivers, due to the importance of water in all the daily activities of the people. Under the technological perspective, water represented a great importance in the agricultural and industrial development in Brazil, since it was one of the main sources of driving power for the agribusiness mills, as well as those of mining and the separation of minerals. That historical construction is carried out with the analysis of texts together with images, such as maritime and fluvial charts; profiles of cities; urban plans.

The modules are integrated by the articulation among the instructors and, above all, by the proposition of an integrated field activity. The itinerary will travel through the Pirajuçara basin and its main tributaries, with the observation in loco and discussion of the physical environment aspects, the historical aspects, those concerning use and occupation, of the social and environmental problems. Data will be gathered with photographic record and elaboration of an itinerary that may be used by the teachers in their classes, with the possibility to take the students 
to carry out activities, such as the study of the environment. Observations will be made of the quality of the river waters in the basin, of the occupation pattern and of the environmental problems generated by the absence of planning of the basin occupation, the structural undertakings carried out by the public power (adjustment of canals, tanks).

The course is in progress, but a brief assessment of its development can be made due to the meeting of the demands of the professors and of the need that they present to develop an integrated vision of reality. The course has been providing subsidies for the professors to review their curricula, reformulating them based on a local perspective, and it creates the opportunity to practice interdisciplinarity, integration and the debate of the role the school plays in face of the environmental realities.

\section{Final thoughts}

Morin $(2003,2004)$ states that, in order for us to prepare ourselves to face the crisis in which the current society is inserted and of the future generations, it's necessary that we change our way of seeing the world and that we move towards an understanding of the complexity of reality. According to the author, our civilization and, consequently, our teaching privilege the separation of the contents to the detriment of the connection, and the analysis to the detriment of the synthesis disunites the objects among themselves. With the isolation of the objects from their natural context and from the set of which it is part, is a cognitive need to insert a specific knowledge in its context and to place it in its whole, which is imperative in education.

The contextualization develops a thought which places every happening, information or knowledge in relation of inseparability with their environment social, cultural, economic, political and natural - and incites the perception of how the former changes it or explains it in another way, becoming a complex thought.

Thus, it becomes crucial to understand the complexity of the relationship man-nature in the local reality. Such understanding in the school, by means of the training of teachers and students, is what may make the difference in the formation of individuals who criticize, participate, who are ready to face the environmental problems and a possible crisis of the available natural resources, among which is water.

\section{Bibliographic references}

AB'SABER, A. N. (Org.) Conceituando educação ambiental. Rio de Janeiro: CNPq; Museu de Astronomia e Ciências Afins, 1991.

ABRANTES, P. Imagens de natureza, imagens de ciência. Campinas: Papirus, 1998.

BRAGA, A. R. et al. Educação ambiental para gestão de recursos hídricos. Livro de Orientação ao Educador. Americana: Consórcio PCJ, 2003. 25lp., il.

BRASIL. Lei n.8.171, de 1991. Lei Nacional da Política Agrária. Diário Oficial da União, Brasília, 18.1.1991. 
Lei n.9.433, 8 jan. 1997. Política Nacional de Recursos Hídricos. Diário Oficial da União, Brasília, 1997.

CARVA LHO, I. C. M. Educação ambiental: a formação do sujeito ecológico. São Paulo: Cortez, 2004.

COMPIANI, M. Geologia/Geociências no Ensino Fundamental e a Formação de Professores. Revista do Instituto de Geologia USP. Public. Espec., São Paulo, v.3, p.1330.2005 .

Ensaios de interdisciplinaridade no Ensino Fundamental com Geologia/ Geociências. In: PONTUSCHKA, N. N.; OLIVEIRA A. U. (Org.) Geografia em perspectiva. 3.ed. São Paulo: Contexto, 2006.

. O lugar e as escalas e suas dimensões horizontal e vertical nos trabalhos práticos: implicações para o ensino de ciências e educação ambiental. Ciência \& Educação, v.13, n.1, p.29-45, 2007.

COMPIANI, M.; CARNEIRO, C. R. Os papéis didáticos das excursões geológicas. Enseñanza de las Ciencias de La Tierra, v.1.2, p.90-8, 1993.

DE LA CORTE, M.; FIGUEIREDO, R. L. A trajetória de uma inovação curricularentre duas disciplinas (Biologia e Geografia) a partir do ambiente local norteado pelo ciclo da água. In: I SIMPÓSIO DE PESQUISA EM ENSINO E HISTÓRIA DE CIÊNCIAS DA TERRA. III Simpósio Nacional sobre Ensino de Geologia no Brasil. Campinas, SP, 2007. p.45-50.

GONÇALVES, P. V. Ensino de Ciência do Sistema Terra e formação continuada de professores em efetivo exercício. Relatório Técnico. Unicamp, 2006.

GRÜN, M. Ética e educação ambiental: a conexão necessária. Campinas: Papirus, 1996. (Coleção Magistério: Formação e Trabalho Pedagógico).

GUIMARÃES, E. M. A contribuição da Geologia na construção de um Padrão de Referência do Mundo Físico na Educação Básica. Revista Brasileira de Geociências, n.34, p.87-94, 2004.

GUIMARÃES, M. Educação ambiental crítica. In: MINISTÉRIO DO MEIO AMBIENTE. Identidade da educação ambiental brasileira. Org. Philippe Layrargues. Brasília, 2004. p.25-34.

Armadilha paradigmática na educação ambiental. In: LOUREIRO, C. F. L. B. et al. (Org.) Pensamento complexo, dialética e educação ambiental. São Paulo: Cortez, 2006.

HAGY, R. D.; VILLANOVA, G. L. Ciclo da água e a urbanização: um estudo do meio (microbacia de drenagem do córrego dos Campos) com alunos da terceira série do ensino médio. In: I SIMPÓSIO DE PESQUISA EM ENSINO E HISTÓRIA DE CIÊNCIAS DA TERRA. III Simpósio Nacional sobre Ensino de Geologia no Brasil Campinas, SP, 2007. p.119-24.

JACOBI, P. R. A cidade e o meio ambiente. São Paulo: Annablume, 1999.

. Educação ambiental: o desafio da construção de um pensamento crítico, complexo e reflexivo. Educação e Pesquisa, v.31, n.2, p.233-50, 2005.

LEAL, A. C.; SUDO, H. Educação ambiental e gestão de recursos hídricos: experiências na graduação e educação continuada de professores do ensino fundamental. In: SIMPÓSIO INTERNACIONAL SOBRE GESTÃO DE RECURSOS HÍDRICOS, 1998, Gramado, RS. Anais... Gramado: ABRH, 1998. 
LORIERI, M. A. Filosofia: fundamentos e métodos. São Paulo: Cortez, 2002.

LOUREIRO, C. F. B. Educação ambiental transformadora. In: MINISTÉRIO DO

MEIO AMBIENTE. Identidade da educação ambiental brasileira. Org. Philippe Layrargues. Brasília, 2004. p.65-84.

LUCATTO , L. G.; TA LAMONI, J. L. B. A construção coletiva interdisciplinar em educação ambiental no ensino médio: a microbacia hidrográfica do Ribeirão dos Peixes como tema gerador. Ciência \& Educação, v.13, n.3, p.389-98, 2007.

MORIN, E. Os sete saberes necessários à educação do futuro. Trad. Catarina Eleonora F. da Silva e Jeanne Sawaya; revisão técnica de Edgard de Assis Carvalho. 8.ed. São Paulo: Cortez; Brasília: Unesco. 2003. p.118.

. A cabeça bem-feita: repensar a reforma, reformar o pensamento. Trad. Eloá Jacobina. 9.ed. Rio de Janeiro: Bertrand Brasil, 2004. p.128.

PONTUSCHKA, N. N. et al. Para ensinar e aprender Geografia. São Paulo: Cortez, 2007. (Coleção Docência em Formação. Série Ensino Fundamental).

ROMERA E SILVA, P. A. Água: quem vive sem? 2.ed. São Paulo: FCTH/CT-Hidro (ANA, CNPq/SNRH), 2004.

ROSI, P. Os filósofos e as máquinas. São Paulo: Cia. das Letras, 1989.

SÃO PAULO (Estado). Secretaria da Educação. Coordenadoria de Estudos e Normas Pedagógicas. Água Hoje e Sempre: consumo sustentável. Secretaria da Educação. São Paulo: SE/Cenp, 2004. 256p., il.

SOFFIAT I, A. As raízes da crise ecológica atual. Ciência e Cultura, v.39, n.10, p.951-4, 1992.

TUCCI, C. E. M. Hidrologia: ciência e aplicação. Porto Alegre: Ed. da Universidade; ABRH; Edusp, 1993.

. Água no meio urbano. In: REBOUÇAS, A. C. et al. (Org.) Águas doces no Brasil: capital ecológico, uso e conservação. São Paulo: Escrituras, 1999.

TUNDISI, J. G. Roteiro de excursão à bacia hidrográfica do ribeirão do Lobo e à represa do Lobo (BROA). São Carlos: CDCC-USP, 1996. (Projeto EDUC@R. Educação Ambiental através do estudo de bacia hidrográfica e qualidade da água).

Novas perspectivas para a gestão de recursos hídricos. Revista USP, São Paulo, n.70, p.24-35, 2006.

TUNDISI, J. G. et al. A utilização do conceito de bacia hidrográfica como unidade para atualização de professores de Ciências e Geografia: o modelo Lobo (Broa) - Brotas /

Itirapina. In: . (Org.) Liminologia e manejo de represas. São Carlos: USP, 1988. p.311-57. (Série Monografia). 
ABSTRACT - The water as subject in the education context should be boarded from several perspectives. With a view to the current discussions regarding the socioenvironmental crisis, we believe that the education for the water should be carried out from two dimensions: spatial and temporal, the last one considering geological time and human history and without these perspectives are not possible to face the fragmentation of the knowledge that predominates in scholar environment. For a construction of a new knowledge, the hydrographic basin as a unity of study provides an integrated vision, aided by Geosciences and interdisciplinary methodologies.

KEYWORDS - Water, Interdisciplinary, Hydrographical basin, Environmental education, Geosciences.

Denise de La Corte Bacci is a Master and PhD from the Department of Sedimentary and Environmental Geology, Institute of Geosciences - IGc/US P. @ - bacci@igc.usp.br

Ermelinda Moutinho Pataca is a Master and $\mathrm{PhD}$ from the Department of Teaching Methodology and Compared Education, School of Education - FE/US P. @ ermelinda.pataca@gmail.com

Received on 7.3.2008 and accepted on 7.9.2008.

Translated by Rodrigo Sardenberg. The original in Portuguese is available at http://www.scielo.br/scielo.php?script=sci_issuetoc\&pid=0103$401420080002 \& \operatorname{lng}=$ pt\&nrm=iso. 